\title{
INFLUENCE OF WATER HYACINTH (EICHHORNIA CRASSIPES (MART.) SOLMS) AND COWDUNG ON SOIL CHEMICAL PROPERTIES AND GROWTH OF OKRA (ABELMOSCHUS ESCULENTUS (L.) MOENCH)
}

\author{
$\underline{\text { Ibrahim Alhassan SALIHU }}^{1 *}$, Adamu Aliyu ALIERO², Musa AUDU³, \\ Hassan Muhammad MAISHANU², Abubakar Alhaji LIMAN, \\ Muhammad Liman MUHAMMAD ${ }^{1}$ \\ ${ }^{1}$ Department of Plant Biology, Federal University of Technology, Minna - Nigeria \\ ${ }^{2}$ Department of Biological Sciences, Usmanu Danfodiyo University, Sokoto -Nigeria \\ ${ }^{3}$ Department of Soil Science and Agricultural Engineering, Usmanu Danfodiyo University, Sokoto -Nigeria \\ ${ }^{4}$ Federal College of Fisheries Technology, New-Bussa - Nigeria \\ *Corresponding author. Email: siaattahiru@yahoo.com
}

\begin{abstract}
This study evaluated the effect of Cow dung and Water Hyacinth (Eichhornia crassipes) on soil chemical properties, growth and yield of Okra (Abelmoschus esculentus). The study was conducted at the Department of Biological Sciences Garden of Usmanu Danfodiyo University, Sokoto in 2012/2013 wet season. The treatments consisted of cow dung (CD) and water hyacinth (WH) each at 0, 5, 10, 20 and 40\% concentration incorporated with the top soil. The experiment was arranged in Randomized Complete Block Design (RCBD), replicated five times. Soil chemical analysis for $\mathrm{pH}$, \%Org. M, \%Org. C, \%N, P, K, Na, Ca, Mg and C.E.C. was carried out before and after planting using standard methods of soil analysis, chemical content of $\mathrm{CD}$ and WH were determined. The results shows that both $\mathrm{CD}$ and $\mathrm{WH}$ enhanced soil chemical contents and at $40 \%$ application of CD and WH organic matter, N, P and C.E.C. of the soil. Numbers of leaves, leaf length, number of fruits, fruit dry weight, stalk dry weight and root length were taken for ten weeks, 2 weeks after planting (2WAP). The result revealed that plant height and numbers of leaves of okra were significantly $(\mathrm{p}<0.05)$ affected with $\mathrm{CD}$ and $\mathrm{WH}$. The application of CD and $\mathrm{WH}$ at $5 \%$ enhanced growth and yield of okra, as well as the soil nutrients status. Application of CD increased plant height and numbers of leaves in Okra more than WH this suggest their potential in ameliorating soil nutrient status and growth of okra.
\end{abstract}

Keywords: cow dung, growth, mineralization, okra, water hyacinth.

\section{Introduction}

Tropical soils are adversely affected by low soil fertility and erosion, causing deterioration of nutrient status and changes in soil organism populations (Economic Commission of Africa, 2001). Use of inorganic fertilizers can improve crop yield and soil $\mathrm{pH}$, total nutrient content and nutrient availability, but it's limited due to scarcity, high cost, nutrient imbalance and soil acidity. Therefore, use of organic manure as a means of maintaining and increasing soil fertility has been advocated [RODALE, 1984; ALASIRI \& OGUNKEYE, 1999; SMIL, 2000]. Animal manures, when efficiently and effectively used could ensure sustainable crop productivity by immobilizing nutrient that is susceptible to leaching. Nutrients contain in manure are released more slowly and stored for longer time in the soil ensuring longer residual effects to improved root development and higher crop yields [SHARMA \& MITTRA, 1991; ABOU EL-MAGD \& al. 2005]. Manures are usually 
applied at high rate; they give residual effect on the growth and yield of succeeding crops [MAKINDE \& AYOOLA, 2008]. Improvements of environmental conditions as well as the need to reduce cost of fertilizing crops are reason for advocating the use of organic materials [BAYU \& al. 2006] organic manure improve soil fertility by activating soil microbial biomass [AYUSO \& al. 1996]. Application of manure sustains cropping system through better nutrient recycling [EL-SHAKWEER \& al. 1998]. Manures serve as a source of macro and micro- nutrients in available forms, thereby improving the physical and biological properties of the soil [ABOU EL-MAGD \& al. 2006].

Soil fertility over the years have been achieved using traditional resources of farmyard manure and crop residues in composted forms as well as inorganic fertilizer [SRIDHAR \& ADEOYE, 2003]. These however have their attendant constraints in the procurement and application of organic and inorganic manure to improves soil fertility, such as high cost (chemical fertilizers) and relatively low nutrient value (crop residues). One largely overlooked resource available for soil fertility remediation is the use of nontraditional or traditional organic materials such as Eichhornia crassipes which is a common weed and cow dung as an animal waste in the tropic that are generally considered as environmental nuisance in land and rivers where they exist.

Water hyacinth is one of the fastest growing plants knows and reproduces primarily by runners and stolons, which eventually form daughter plant. It produces large quantities of seeds and which could be viable up to thirty years. The common water hyacinth Eichhornia crassipes is vigorous grower known to double their population in two weeks [BARRETH, 1980]. It is also found in lotic water and they are probably brought into such aquatic environment by water current [NDIMELE, 2012]. They are hard, very difficult to eradicate because they can survive in extremely harsh conditions. During unfavorably condition such as drought, the plant sinks into the water and remains dormant until the condition of the environment becomes favorable for growth. Water hyacinth grows well in nutrient rich water but do not tolerate brackish water because of its salinity level [SOOKNAH \& WILKIE, 2004]. The conducive temperature and seasonally or constantly low salinity of River Niger has supported the proliferation of water hyacinth. Coupled with this and its high rate of reproduction has made it a serious threat to the continued use of the affected Nigeria water resources. The rate of aquatic invasion by water hyacinth in Nigeria water bodies is alarming. It forms a thick mat covering rice paddles, blocking canals and channel, impeding navigation, halting fishing, sweeping away building for mosquito [CHUKWUKA \& UKA, 2007; NDIMELE \& al. 2011]. It caused problem to the dependents of Jebba riverine community of River Niger, who use the river for their socioeconomic activity. It impedes water transportation by preventing access to the source of their livelihood and reduces or prevent accessibility to fishing ground especially during the rainy season which is the period when fishing activities is intense and more profitable. This poses a great hindrance to the socio-economic potential of this water if appropriate and effective control is not introduced. This study compares the effects of water hyacinth and cow dung as manure on soil chemical properties and growth performances of okra.

\section{Materials and methods}

The research was conducted in the Biological Sciences Garden of Usmanu Danfodiyo University, Sokoto (which is situated between longitude $5^{\circ} 11^{\prime} 30^{\prime \prime} \mathrm{E}$ and $5^{\circ} 14^{\prime} 30^{\prime \prime} \mathrm{E}$ and latitude $13^{\circ} 8^{\prime} 30^{\prime \prime} \mathrm{N}$ and $13^{\circ} 7^{\prime} 0^{\prime \prime} \mathrm{N}$ of Wamako Local Government Area of 
Ibrahim Alhassan SALIHU \& al.

Sokoto State [MAISHANU \& al. 2017]. The research started on $15^{\text {th }}$ June, 2012 and ended on $29^{\text {th }}$ August, 2012.

Water hyacinth sample were collected from river Niger, down hydro-power station dam in Jebba, which is in the border between Kwara and Niger state on latitude $9^{\circ} 10^{\prime}$ to $9^{\circ}$ $55^{\prime} \mathrm{N}$ and longitudes $4^{\circ} 30^{\prime} \mathrm{E}$ to $5^{\circ} 00^{\prime} \mathrm{E}$ [ADENIJI, 1991]. The samples were collected on $4^{\text {th }}$ March, 2012, air-dried for 6 weeks and pulverized by grinding. The cow dung was collected from cattle ranch close to the postgraduate hostel of Usmanu Danfodiyo University, Sokoto. Seeds of Abelmoschus esculentus Ex-Sokoto (a local variety from vegetable growers at Kwalkwalawa, Village Sokoto), were collected from Sokoto central market.

Proximate and mineral analysis of Water Hyacinth and cow dung were carried out according to methods described by PIRIE (1955). The following parameters were determined: Moisture content, Ash content, crude fibres, Crude lipid, Nitrogen and Crude protein, Carbohydrate, Phosphorous, Sodium, Potassium, Calcium, Magnesium and Nitrogen. Soil pH, Carbon, Potassium, Calcium Magnesium and Nitrogen before and after planting were determined following methods described by URIYO \& SINGH (1974).

\section{Experiment design and treatment}

The experiment was arranged in a randomized complete block design with 10 treatments in 5 replications. The treatments consisted of 5 concentrations $(0,5,10,20$, and $40 \%$ ) each of residual form of Water hyacinth, and cow dung. Each concentration was incorporated into $10 \mathrm{~kg}$ of garden soil. The experiment was conducted in the polythene bags which were all perforated for aeration and placed in open space of Biological Sciences. Both the water hyacinth and cow dung manure were applied to the soil 7days before planting. Data on plant height, number of leaves, leaf length and root length, were taken in two weeks' interval, while fruits per plant were also counted. Dry matter on fruits and stalk were taken after drying in an oven at $120^{\circ} \mathrm{C}$ for 72 hours.

\section{Data analysis}

The data obtained from soil and okra plant were subjected to statistical analysis of variance using the mixed model procedure in SPSS Version 20, and Significant means were separated using least significant difference (LSD). Mean value was used to compare the baseline proximate composition and mineral contents of cow dung and Water hyacinth.

\section{Results and discussion}

\section{Chemical analysis of cow dung and Water Hyacinth}

Result of proximate and mineral analysis of cow dung and water hyacinth is presented in Table 1. Cow dung higher \% Ash and \% Fibre compared to Water Hyacinth. Conversely, Water Hyacinth had significantly higher \% moisture, \% Lipid, \% Carbohydrate, Calcium and Magnesium than Cow dung. However, there were no significant differences between cow dung and Water Hyacinth in their \% Nitrogen, \% Crude protein, Phosphorus, Sodium and Potassium. The content of calcium and magnesium content was 47.65 and $6.84 \mathrm{mg} / \mathrm{kg}$ respectively in water hyacinth while their values in cow dung were comparatively low. 


\section{Effect of cow dung and Water Hyacinth on chemical properties of soil before} and after planting

The result of soil analysis prior to planting and after planting is presented in Table 2. There was no significant difference in soil $\mathrm{pH}$, before and after amendment with cow dung and water hyacinth. Different combinations (Concentrations) of Cow dung and Water Hyacinth had significant effects on soil pH. There was no significant interaction between manures and concentration in $\mathrm{pH}$ value. The organic matter content of $71.30 \%$ was obtained in the soil prior to planting and significant $(\mathrm{p}<0.001)$ difference was observed between the treatments, with highest value of $1.71 \%$ in water hyacinth amended soil and $0.72 \%$ in cow dung. The same trend was observed in varying the concentration of the treatments with highest value of $2.16 \%$ recorded from $5 \%$ concentration and $20 \%$ concentration gave the least value of $0.70 \%$. There was significant $(\mathrm{p}<0.01)$ difference in interaction between manures and concentration in the values of organic matter. Percentage carbon prior to planting was $0.75 \%$, but significant $(\mathrm{p}<0.001)$ difference was observed between the treatments, with highest value of $1.07 \%$ in water hyacinth and cow dung had the least value of 0.42 . The percentage organic carbon was significantly $(p<0.01)$ affected by concentration, highest value of $1.25 \%$ in $5 \%$ concentration and the least value of $0.40 \%$ organic carbon was obtained from $20 \%$ concentration. There was a significant $(p<0.01)$ interaction between the manures and concentration in the content of organic carbon. The percentage nitrogen prior to amendment was $0.05 \%$, but significant $(\mathrm{p}<0.001)$ difference was observed between the treatments, with highest value of $0.47 \%$ in cow dung and least value of $0.25 \%$ in water hyacinth, similar trend was also observed in varying the concentration of the treatment with $0.84 \%$ recorded from $40 \%$ concentration and $0.11 \%$ from control soil. There was no significant effect in interaction between manures and concentration in percentage nitrogen.

Phosphorus content of the soil prior to planting was $0.22 \mathrm{mg} / \mathrm{kg}$, while significant ( $<<0.001$ ) difference was observed between the treatments with $4.10 \mathrm{mg} / \mathrm{kg}$ in cow dung as the highest value and water hyacinth had $3.08 \mathrm{mg} / \mathrm{kg}$. The same trend was observed in concentration of the treatments with highest value of $4.33 \mathrm{mg} / \mathrm{kg}$ recorded from $40 \%$ concentration and lowest value of $2.26(\mathrm{mg} / \mathrm{kg})$ from the control soil. There was significant $(\mathrm{p}<0.001)$ difference in interaction between manures and concentration in phosphorous content.

The calcium content of the soil prior to planting was $0.37 \mathrm{cmol} / \mathrm{kg}$, but there was significant $(\mathrm{p}<0.05)$ difference between the treatments and water hyacinth had the highest with $0.67 \mathrm{cmol} / \mathrm{kg}$ and lowest of $0.53 \mathrm{cmol} / \mathrm{kg}$ was recorded in cow dung. However, there was no significant effect of concentration on the calcium content. Manure and concentration interaction effect on calcium content was not significant. Magnesium content of the soil prior to planting was $0.83 \mathrm{cmol} / \mathrm{kg}$. There was no significant effect between cow dung and water hyacinth, and concentrations of treatments on magnesium content. However, interaction effect was significant with $0.22 \mathrm{cmol} / \mathrm{kg}$ of potassium prior to planting. The manures, their concentrations, and interaction had no significant effect on potassium content of the soil. Initial content of sodium prior to planting was $0.63 \mathrm{cmol} / \mathrm{kg}$. Cow dung treatment had significantly higher sodium content $0.70 \mathrm{cmol} / \mathrm{kg}$ than water hyacinth $0.35 \mathrm{cmol} / \mathrm{kg}$. Although concentration had no significant $(\mathrm{p}>0.05)$ effect on the values of sodium the interaction effect was significant. Finally, $2.14 \mathrm{cmol} / \mathrm{kg}$ was observed prior to planting for the cation exchange capacity (C.E.C.) of the soil. Soil treated with cow dung had significantly higher $(\mathrm{p}<0.001)$ C.E.C. value of $4.53 \mathrm{cmol} / \mathrm{kg}$ than soil amended with water hyacinth $2.17 \mathrm{cmol} / \mathrm{kg}$. 
Ibrahim Alhassan SALIHU \& al.

There was a significant $(\mathrm{P}<0.001)$ effect of varying concentration on the C.E.C. value with $4.41 \mathrm{cmol} / \mathrm{kg}$ in $5 \%$ concentration and $2.63 \mathrm{cmol} / \mathrm{kg}$ from the control soil. There is significant interaction between the manure and concentration on soil C.E.C.

\section{Effect of cow dung and Water hyacinth on growth and yield attributes of okra plant}

Results in Table 3 showed the height of Okra grown in soils amended with cow dung and water hyacinth manure and showed a significant $(\mathrm{p}<0.05)$ from the $6^{\text {th }}$ to the $10^{\text {th }}$ week after planting with plants grown in cow dung amended soils being consistently taller. However, variation between the treatment's concentrations were not significant. Table 4 shows the mean effect of manure and their concentrations on number of leaves. The result obtained at week two and six, showed there were no significant $(p>0.05)$ effect of the treatments, whereas the effect was significant $(\mathrm{p}<0.05)$ in week four with cow dung given the highest mean value of 8.0 followed by the water hyacinth with mean value of $7.4 \mathrm{~cm}$. At week eight there was significant $(\mathrm{p}<0.01)$ difference, where the cow dung recorded highest mean value of $8.32 \mathrm{~cm}$ and the water hyacinth gave $5.68 \mathrm{~cm}$. At week ten there was a significant $(\mathrm{p}<0.01)$ effect in numbers of leaves, the cow dung recorded the highest mean value of $6.80 \mathrm{~cm}$, while the least value of $5.04 \mathrm{~cm}$ was recorded from the water hyacinth. However, there was no significant effect $(\mathrm{p}>0.05)$ on the numbers of leaves throughout the period of the trial. Similarly, leaf length was not affected significantly ( $p>0.05)$ by manure and concentration (Table 5) as well as root length, dry matter and numbers of fruits (Table 6) throughout the period of the experiment.

Table 1.Baseline mean values for proximate analysis of cow dung and Water Hyacinth.

\begin{tabular}{ccc}
\hline Parameters & Cow dung & Water hyacinth \\
\hline \% Moisture & 8.2 & 9.17 \\
\%Ash & 47 & 14.17 \\
\%Lipid & 1.5 & 10.17 \\
\%Fibre & 12 & 2.70 \\
\hline \%Nitrogen & 0.94 & 0.62 \\
\%Crude protein & 5.88 & 3.85 \\
\hline \%Carbohydrate & 33.07 & 69.15 \\
\hline Phosphorous(mg/kg) & 98.59 & 97.50 \\
\hline Sodium(mg/kg) & 0.81 & 1.11 \\
\hline Potassium(mg/kg) & 1.89 & 2.85 \\
\hline Calcium(cmol/kg) & 0.35 & 47.65 \\
\hline Magnesium(mg/kg) & 0.6 & 6.84 \\
\hline
\end{tabular}


Table 2. The effect of cow dung and Water Hyacinth on soil chemical parameters.

\begin{tabular}{|c|c|c|c|c|c|c|c|c|c|c|}
\hline \multirow[b]{2}{*}{ Treatment } & \multicolumn{10}{|c|}{ Parameters } \\
\hline & pH & \%Org.M & \%Org.C & $\% \mathbf{N}$ & P(mg/kg) & Ca & Mg & $\begin{array}{c}\mathrm{cmol} / \mathrm{Kg} \\
\mathrm{K}\end{array}$ & $\mathrm{Na}$ & CEC \\
\hline Before Planting & 6.67 & 1.30 & 0.75 & 0.05 & 0.22 & 0.37 & 0.83 & 0.22 & 0.63 & 2.41 \\
\hline \multicolumn{11}{|l|}{ Manure: } \\
\hline CD & 6.51 & 0.72 & 0.42 & 0.47 & 4.10 & 0.53 & 0.99 & 0.28 & 0.70 & 4.53 \\
\hline WH & 6.59 & 1.71 & 1.07 & 0.25 & 3.08 & 0.67 & 1.04 & 0.25 & 0.35 & 2.17 \\
\hline $\mathrm{SE} \pm$ & 0.05 & 0.91 & 0.11 & 0.03 & 0.06 & 0.05 & 0.06 & 0.02 & 0.07 & 0.07 \\
\hline LSD & Ns & $0.000^{* * *}$ & $0.000^{* * * *}$ & $0.000^{* * *}$ & $0.000^{* * *}$ & $0.004^{*}$ & Ns & Ns & $0.000^{* * *}$ & $0.000^{* * *}$ \\
\hline \multicolumn{11}{|l|}{$\begin{array}{l}\text { Concentration } \\
\text { (\%)CD/WH }\end{array}$} \\
\hline 5 & 6.41 & 2.16 & 1.25 & 0.14 & 3.71 & 0.58 & 1.12 & 0.26 & 0.57 & 4.41 \\
\hline 10 & 6.53 & 0.99 & 0.57 & 0.24 & 3.77 & 0.58 & 1.07 & 0.29 & 0.46 & 3.14 \\
\hline 20 & 6.61 & 0.70 & 0.40 & 0.46 & 3.50 & 0.62 & 1.02 & 0.22 & 0.35 & 3.65 \\
\hline 40 & 6.68 & 1.22 & 0.71 & 0.84 & 4.33 & 0.62 & 0.95 & 0.33 & 0.54 & 2.90 \\
\hline 0 & 6.54 & 1.00 & 0.77 & 0.11 & 2.62 & 0.62 & 0.92 & 0.25 & 0.70 & 2.63 \\
\hline SE \pm & 0.08 & 0.30 & 0.17 & 0.05 & 0.10 & 0.08 & 0.09 & 0.04 & 0.11 & 0.11 \\
\hline LSD & Ns & $0.003^{* *}$ & $0.008^{* *}$ & Ns & $0.000^{* * *}$ & Ns & $0.007^{*}$ & Ns & $0.013^{*}$ & $0.000^{* * *}$ \\
\hline
\end{tabular}

Table 3. Effect of cow dung and Water Hyacinth on plant height in Okra.

\begin{tabular}{|c|c|c|c|c|c|}
\hline \multirow{2}{*}{ Treatment } & \multicolumn{5}{|c|}{ WAP } \\
\hline & 2 & 4 & 6 & 8 & 10 \\
\hline \multicolumn{6}{|l|}{ Manure } \\
\hline Cow dung & 7.61 & 18.92 & 32.10 & 55.70 & 55.9 \\
\hline Water Hyacinth & 7.33 & 17.66 & 27.00 & 44.90 & 44.9 \\
\hline SE \pm & 0.627 & 1.257 & 2.33 & 4.14 & 4.18 \\
\hline LSD & Ns & Ns & $0.036^{*}$ & $0.013^{*}$ & $0.013^{*}$ \\
\hline \multicolumn{6}{|l|}{$\begin{array}{l}\text { Concentration (\%) } \\
\text { CD/WH }\end{array}$} \\
\hline 0 & 7.58 & 20.08 & 25.6 & 50.4 & 51.4 \\
\hline 5 & 7.02 & 16.21 & 30.5 & 51.0 & 51.2 \\
\hline 10 & 6.36 & 15.94 & 28.6 & 47.7 & 47.8 \\
\hline 20 & 8.48 & 19.27 & 31.1 & 49.8 & 49.7 \\
\hline 40 & 7.92 & 19.95 & 31.9 & 52.7 & 52.0 \\
\hline $\begin{array}{l}\mathrm{SE} \pm \\
\mathrm{LSD}\end{array}$ & $\begin{array}{l}0.99 \\
\text { Ns }\end{array}$ & $\begin{array}{l}1.99 \\
\text { Ns }\end{array}$ & $\begin{array}{l}3.69 \\
\text { Ns }\end{array}$ & $\begin{array}{l}6.55 \\
\text { Ns }\end{array}$ & $\begin{array}{l}6.61 \\
\text { Ns }\end{array}$ \\
\hline
\end{tabular}


Ibrahim Alhassan SALIHU \& al.

Table 4. Effect of cow dung and Water Hyacinth on the number of leaves.

\begin{tabular}{|c|c|c|c|c|c|}
\hline \multirow{2}{*}{ Treatment } & \multicolumn{5}{|c|}{ WAP } \\
\hline & 2 & 4 & 6 & 8 & 10 \\
\hline \multicolumn{6}{|l|}{ Manure } \\
\hline Cow dung & 4.20 & 8.32 & 8.52 & 8.32 & 6.80 \\
\hline Water Hyacinth & 4.28 & 7.4 & 8.04 & 5.68 & 5.04 \\
\hline $\mathrm{SE} \pm$ & 0.34 & 0.54 & 0.58 & 0.71 & 0.58 \\
\hline LSD & Ns & $0.024^{*}$ & Ns & $0.001^{* * *}$ & $0.005^{* *}$ \\
\hline \multicolumn{6}{|l|}{$\begin{array}{l}\text { Concentration (\%) } \\
\text { CD/WH }\end{array}$} \\
\hline 0 & 4.70 & 8.20 & 7.00 & 6.90 & 5.00 \\
\hline 5 & 4.60 & 8.00 & 8.30 & 7.50 & 6.10 \\
\hline 10 & 4.00 & 6.50 & 7.50 & 5.90 & 5.20 \\
\hline 20 & 4.10 & 8.40 & 9.70 & 7.80 & 6.90 \\
\hline 40 & 3.80 & 7.30 & 8.20 & 6.90 & 6.40 \\
\hline $\mathrm{SE} \pm$ & 1.09 & 0.86 & 0.92 & 1.12 & 0.92 \\
\hline LSD & Ns & Ns & Ns & Ns & Ns \\
\hline
\end{tabular}

Table 5. Effect of cow dung and Water Hyacinth on the leaf length.

\begin{tabular}{lccccc}
\hline \multirow{2}{*}{ Treatment } & \multicolumn{5}{c}{ WAP } \\
\cline { 2 - 5 } Manure & $\mathbf{2}$ & $\mathbf{4}$ & $\mathbf{6}$ & $\mathbf{8}$ & $\mathbf{1 0}$ \\
\hline Cow dung & 3.56 & 10.14 & 10.05 & 9.98 & 9.23 \\
Water Hyacinth & 3.08 & 9.11 & 10.86 & 9.30 & 8.42 \\
SE \pm & 0.27 & 0.66 & 0.68 & 0.63 & 0.63 \\
LSD & Ns & Ns & Ns & Ns & Ns \\
Concentration (\%) & & & & \\
CD/WH & & & & 8.96 & 8.20 \\
0 & 3.63 & 10.06 & 9.69 & 10.67 & 9.17 \\
5 & 3.46 & 10.25 & 10.91 & 8.68 & 8.19 \\
10 & 3.20 & 9.12 & 10.00 & 10.68 & 9.76 \\
20 & 3.40 & 10.00 & 11.34 & 9.23 & 8.79 \\
40 & 2.92 & 8.69 & 10.35 & 1.00 & 1.00 \\
SE \pm & 0.43 & 1.05 & 1.08 & Ns & Ns \\
LSD & Ns & Ns & Ns & \\
\hline Ns $=$ no significant effect at 5\% probability level. WAP $=$ Weeks after planting SE $=$ Standard error
\end{tabular}


Table 6. Effect of cow dung and Water Hyacinth on the number of fruits, root length and dry matter: (Stalk Dry Weight and Fruit Dry Weight).

\begin{tabular}{lcccc}
\hline \multirow{2}{*}{ Treatment } & \multicolumn{3}{c}{ WAP } \\
\cline { 2 - 4 } Manure & NoF & RL $(\mathbf{c m})$ & StlkDW & FrtDW \\
\hline Cowdung & 2.08 & 15.63 & 4.71 & 33.6 \\
Water Hyacinth & 1.80 & 12.92 & 5.67 & 30.3 \\
SED \pm & 0.45 & 1.97 & 0.64 & 2.96 \\
LSD & Ns & Ns & Ns & Ns \\
Concentration (\%) & & & & \\
CD/WH & & & 5.28 & 32.1 \\
$0 \%$ & 1.60 & 11.60 & 3.39 & 34.4 \\
$5 \%$ & 2.20 & 13.37 & 3.29 & 30.4 \\
$10 \%$ & 1.80 & 13.37 & 6.00 & 28.7 \\
$20 \%$ & 2.20 & 15.87 & 5.99 & 4.69 \\
$40 \%$ & 1.90 & 17.96 & 1.01 & Ns \\
SE \pm & 0.78 & 3.12 & Ns & \\
LSD & Ns & Ns & & \\
\hline
\end{tabular}

ns = no significant effect at 5\% probability level.

NoF $=$ Number of fruits, RL = root length, StkDW = Stalk dry weight, FrtDW = Fruit dry weight.

\section{Discussion}

Proximate and mineral analysis of both cow dung and water hyacinth used in this study showed that they varied in their nutrient composition. The low moisture content of water hyacinth observed may be as result of presence of cellulose, hemicellulose and pectin that are likely higher in cow dung, and are insoluble in water, which is in line with the findings of NUKA \& DUBEY (2011), who reported the response of water hyacinth manure contribute to the nitrogen availability released during mineralization on growth and yield of Brassica juncea. The high ash content observed in cow dung may be as result of nature of plants on which the animals feed, and is contrary to the findings of NUKA \& DUBEY (2011), who reported the response of water hyacinth manure on growth attribute of Brassica juncea with low ash content. High lipid content was observed in water hyacinth followed by cow dung. This may be attributed to the high level of lignin, present in water hyacinth which is oily in nature, this goes contrary to the finding of NGULDE \& al. (2018), who reported higher amount of lipids in cow dung. The fibre content of cow dung was higher than, that of water hyacinths this may be as a result of types and nature of plant materials the animals feed on. There was no significant difference in the percentage nitrogen of cow dung and water hyacinth, though value obtained from cow dung was slightly higher compared to waters hyacinth, the low content of nitrogen in water hyacinth may be as a result of incomplete mineralization of in the two manure. This is also in line with the reports of MAKINDE \& al. (2011), who reported effect of mineral fertilizer and organic manure on growth, nutrient content and yield of Cassava plant and observed complete mineralization in inorganic fertilizer while incomplete mineralization took place inorganic manure. However, percentage carbohydrate in water hyacinth was higher than that of cow dung. This may be attributed to fact that the plant has the ability to synthesis their own carbon compound while the Cow that produces the dung depend on the plants for their carbon compound. This is contrary to the finding of NUKA \& DUBEY (2011) who investigate the effect of water hyacinth manure on growth of India Mustard plant and reported low amount of carbon compound from the water hyacinth. The phosphorous 
content of cow dung was slightly higher than that of water hyacinth, sodium, potassium does not show much difference. Similar trend was reported by NUKA \& DUBEY (2011) and MAKINDE \& AYOOLA (2012). However, the calcium content of water hyacinth was very high compared to that of cow dung; this is also in line with the findings of MAKINDE \& AYOOLA (2012) who reported the growth and yield of okra using cow dung and poultry manure. High content of magnesium was found in water hyacinth and cow dung, the magnesium content of water hyacinth was more than that of cow dung this also corroborates with the findings of NUKA \& DUBEY (2011), they recorded high amount of magnesium in water hyacinth compared to cow dung.

The soil analysis before planting showed that the soil $\mathrm{pH}$ was slightly acidic, however, at post-harvest $40 \%$ concentration gave the highest value of $\mathrm{pH}$, while the least value was recorded from $5 \%$ concentration. The slightly acidic condition may be due to the fact that Sokoto State is in semi-arid region, and one of the characteristics of soil of this region is its neutral to slightly acidic nature, which is in agreement with the finding of SHUKRY \& al. (2007), who recorded high amount of $\mathrm{pH}$ in calcareous soil on growth vigour, water relations, mineral uptake and content of fatty acid and protein of Flax plant. High amount of organic matter was recorded from soil amended with water hyacinth followed by control soil. This may be as result of mineralization process, the manures might have undergone. This is in line with the finding of GUNNARSSON \& PETERSON (2007), who reported high amount of organic matter and fast mineralization of water hyacinth in agriculture land and energy production. Highest value was obtained from soil treated with $5 \%$ concentration and soil treated with $20 \%$ concentration gave the least value in terms of interaction between the manure and concentration. This is in conformity with the studies of SHARMA \& MITTRA (1991), on the effect of different rates of application of organic manure. Highest percentage carbon was obtained from soil treated with 5\% water hyacinth, and the least value was obtained from soil treated with $20 \%$ cow dung. This could be attributed to the high amount of organic carbon earlier recorded from the water hyacinth been added to the okra in addition to the synthesis one above the ground. While the low content of carbon in soil treated with cow dung may be as result of dependence of animals on plant materials for carbon compound. This is contrary to the finding of NUKA \& DUBEY (2011), who reported high amount of organic carbon in soil amended with water hyacinth. This is in line with the finding of OKWUAGWU \& al. (2003), who confirm effect of organic and inorganic manure on soil properties and yield of okra. Soil treated with cow dung gave the highest value of nitrogen, and the least value was observed in control soil. This may be as result of actions of digestives enzymes that might have acted on plant material eaten by the animals before being used as organic manure, which may in turn hasten the mineralization process of cow dung. This is in line with the finding of ZAMAN \& al. (2017), who reported gradual increase of soil nitrogen amended with cow dung at varying concentration. However, there was significant effect in nitrogen concentration, with $40 \%$ concentration showing the highest value, while the least value was recorded from the control soil. This may be as result of increment in the application of manures and is in conformity with the finding of WIDJAJANTO \& al. (2001) who conduct studies on the release of nitrogen from water hyacinth incorporated in to soil-crop system. Soil treated with cow dung recorded the highest value of phosphorous while the control soil gave the least value. The high content of phosphorus, in soil treated with cow dung may be attributed to addition of other molecules or ion from the animal excretal or other biomolecules, while the least value showed by the control soil may be due to the fact that phosphorous is the 
most limiting element in the soil. This could be supported by the result of CHUKWUKA \& OMOTAYO (2008), who reported the effect of Tithonia green manure and water hyacinth compost application on nutrient depleted soil and also similar to the finding of WIDJAJANTO \& al. (2001). However, varying the concentration, 40\% concentration had the highest phosphorous content, while the lowest was recorded from the control soil. This could be as a result of enzymes activities that might have taken place on the manures, decomposing them to reasonable extent and is supported by CHUKWUKA \& OMOTAYO (2008). There was interactive effect in phosphorous contents of manures and concentration. The Soil amended with water hyacinth contained high amount of calcium followed by control soil. This may be attributed to the fact that water hyacinth might have added part of its calcium content to the soil. This is in accordance with the findings of OJENIYI \& al. (2013), on effect of organic manure on soil physico-chemical properties, nutrient uptake and yield of cocoyam plant. There was no effect was observed in varying the concentration of the manures. The interaction between the manures and concentration show no effect. This is in line with the finding of CHUKWUKA \& OMOTAYO (2008). There was no favorable effect in magnesium and potassium, but soil treated with water hyacinth gave the highest values while the least value was recorded from control soils. Similarly, there was no significant effect in magnesium and potassium content, in terms of concentration. But significant effect of interaction was observed in magnesium. However, the potassium content does not show any interaction effect. This was supported by the finding of OJENIYI \& al. (2013), who reported the effect of poultry manure on soil physical properties and nutrient uptake of cocoyam. The sodium content of soil treated with cow dung had the highest value while the least value was obtained from the soil amended with water hyacinth. This may be attributed to availability of more $\mathrm{Na}^{+}$in cattle, than the plant material. There was no significant effect in concentration, but effect was observed in interaction between the manures and concentration. This is contrary to the finding of AKANDE \& al. (2010), who reported the response of okra to organic and inorganic fertilizer. The value of CEC recorded from cow dung and least value from water hyacinth, this explains the potentials of cow dung in supplying adequate basic cations as nutrient source than the water hyacinth. This corroborates with the report of OKWUAGWU \& al. (2003), who reported the effect of organic and inorganic manure on soil properties and yield of okra. In varying the concentration of manures, high amount of CEC was recorded from soil treated with 5\% concentration, while the least value was obtained from control soil. Same trend was observed in interaction between the manures and concentration,

There was promising increase in pant height due to the application of organic manure, but the application of cow dung showed more promising increase in plant height compared to water hyacinth, this may be as a result of interaction between the organic manure and growth hormones in the various part of the plant, as reported by ABUSALEHA \& SHAMUGAVETU (1988), using animal manure with inorganic fertilizer as reported by YADAV \& al. (2004). It is also possible that improved growth observed in Okra with the application of organic amendments may be due to the presence of high phosphorous content in both manure which increased the availability of native soil phosphorous and increased biological activity of microbes and a similar opinion had been expressed by SINGH \& SRIVASTAVA (1970). Moreover, there was an appreciable effect on the number of leaves for both treatments. Although cow dung showed more advantageous effect over water hyacinth, which could be supported by the study of SOLOMON \& al. (2012), who reported the effect of cow dung and N.P.K. fertilizer on the growth of maize. Other parameters like 
leaf length, number of fruit/plants, fruit dry weight/plant, stalk dry weight/plant as well as the root length showed no significant effect as a result of the treatments application.

Growth parameters, such as plant height, number of leaves/plant, leaf length/plant, number of fruits, root length/plant, fruit dry weight and stalk dry weight all do not show positive effect even upon varying the concentration of cow dung or water hyacinth from 5$40 \%$. This is in line with the study of SEYEDBAGHERI (1999), who conducted a study on effect of organic fertilizer on the vegetative growth of plants even at maturity stage, high dosage application is recommended from the study.

The cow dung and Water hyacinth do not show any interactive effect on growth and yield parameters, however, cow dung showed favorable effect on plant height and number of leaves. This may be as a result of interaction between the cow dung and growth hormone, more also, plant treated with cow dung might have gotten access to high amount of growth hormone than those treated with water hyacinth. This result is in agreement with that of OLUBUNMI \& al. (2011), who reported an increase in the yield and nutrients uptake in two vegetable plant using poultry manure and contrary to their work at maturity stage, using organic manure and mineral fertilizer, that both organic and in organic fertilizer are effective in vegetative growth of crop and yield.

\section{Conclusion}

The result of this study shows that the application of Cow dung and water hyacinth at different concentration positively influenced some of the parameter studied. Cow dung and water hyacinth application have been found to increase organic matter, organic carbon, $\mathrm{N}, \mathrm{P}, \mathrm{Ca}, \mathrm{Na}$ and CEC of the soil, their application at different concentration also suggest the soil with higher concentration of cow dung or water hyacinth has positive influence on organic matter, organic carbon, $\mathrm{P}, \mathrm{Mg}, \mathrm{Na}$, and CEC of the soil and exert positive influence in the vegetative growth and yield of okra plant. However, cow dung and water hyacinth could be applied in high dose for improved soil fertility and growth and yield of okra.

\section{Notes on contributors}

Ibrahim Alhassan SALIHU is a plant Scientist with specialization in plant physiology and Environmental Biology. He had impacted in several area, like ecology, phytomedicine and phytoremediation. He is presently awaiting $\mathrm{PhD}$ final defense in plant ecophysiology, phytoremediation and competition exhibited by plant native to Mine tailing. He is a Lecturer with the Department of Plant Biology, Federal University of Technology, Minna, Nigeria.

Professor Adamu Aliyu ALIERO (FASI, FRHD) is a Professor of Plant Physiology in the Department of Biological Sciences, Usmanu Danfodiyo University, Sokoto, Nigeria. He had published widely in the areas of Plant Physiology and Genetics. Aliero is a Fellow African Scientific Institute (FASI) Fellow Strategic Institute for Natural Resources and Human Development (FRHD).

Musa AUDU is a Professor of Soil Fertility and Chemistry in the department of Soil Science and Agricultural Engineering, Usmanu Danfodiyo University, Sokoto. He graduated from Moscow Timiryazev Agricultural Academy, Russia in 1996 where he obtained BSc, MSc (Soil Science) and $\mathrm{PhD}$ (Agricultural Chemistry) in the same Academy. His research interest is in Integrated Soil Fertility Management (Fertility, Fertilizer and Environmental Management).

Muhammad Liman MUHAMMAD is Plant geneticist and breeder with special interest in mutation breeding. He holds a $\mathrm{PhD}$ in applied plant genetics and breeding.

Dr. Mohammed Hassan MAISHANU is an associate professor of Botany with special interest in Plant ecology, Plant nutrition, Biodiversity and Conservation. He worked with the Department of Biological Sciences, Usmanu Danfodiyo University, Sokoto, Nigeria. 


\section{Acknowledgement}

The author's appreciation goes to the staffs of Biological Science Department, Usmanu Danfodiyo University, Sokoto for allocating space for us to conduct this study. Our sincere appreciation also goes to late Prof. Abayome of University of Ilorin who help in data analysis. May his soul continue to rest in perfect peace.

\section{References}

ABOU EL-MAGD M. A., EL-BASSIONY M. \& FAWZ Y. Z. F. 2006. Effect of organic manure with or without chemical fertilizer on growth, yield and quantity of some varieties of Broccoli plants. Journal of Applied Science Resources. 2(10): 791-798.

ABUSALEHA M. \& SHANMUGAVELU K. G. 1988. Studies on the effect of organic and inorganic source of nitrogen on growth, yield and quality of Okra. Indian Journal of Horticulture. 45: 312-318. https://doi.org/10.20546/ijcmas.2017.612.297

ADENIJI H. A. 1991. Limnology and biological production in the pelagic zone of Jebba Lake, Nigeria, Ph.D. Thesis, University of Ibadan: 5-9.

AKANDE M. O., OLUWATOINBO F. I., MANKINDE E. A., ADEPOJU A. S. \& ADEPOJU I. S. 2010. Response of Okra to organic and in organic fertilization. Journal of Natural Sciences. 8(11): 216-266.

ALASIRI K. O. \& OGUNKEYE O. O. 1999. Effect of poultry manure on seed yield of Okra. Proceeding of $25^{\text {th }}$ Annual Conference of Soil Science Society of Nigeria, $21^{\text {st }}-25^{\text {th }}$ November, 1999. Benin, Nigeria.

AYUSO M. A., PASCAL J. A., GARCIA C. \& HERMANDE Z. 1996. Stimulation of barley growth and nutrient absorption by humic substances originating from various organic materials. Bioresources Technology. 57: 251-257. https://doi.org/10.1080/03650340.2013.792990

BARRETH S. C. H. 1980. Asexual reproduction in Eichhornia cassipes (water Hyacinth). Fertility of clones from diverse regions. Journal of Applied Ecology. 17:101-112.

BAYU W., RETHMAN N. F. G., HAMMERS P. S. \& ALEMU G. 2006. Effect of farmyard manure and inorganic fertilizer on sorghum growth, yield and nitrogen use in a Semi-arid area of Ethiopia. Journal of Plant Nutrition. 29: 391-407. https://doi.org/10.1080/01904160500320962

CHUKWUKA K. S. \& UKA U. N. 2007. Effect of Water hyacinth Eichhornia crassipes infestation zooplankton population in AWBA Reservoir. Ibadan South-West Nigeria. Journal of Biological Sciences. 7: 865-869.

CHUKWUKA K. S. \& OMOTAYO O. E. 2008. Effect of Tithonia green manure and water Hyacinth compost application on nutrient depleted soil in South-western Nigeria. International Journal of Soil Science. 3(2): 69-74.

Economic Commission of Africa 2001. State of the Environment in Africa. Economic Commission of Africa, Addis Ababa, Ethiopia, ECA/FSSDD/01/06. http:/www.Uneca.org/water/stateEnvironAfri.polf

EL-SHAKWEER M. H. A., EL-SAYED E. A. \& EWEES M. S. A. 1998. Soil and plant analysis as a guide for interpretation of the improvement efficiency of organic conditioners added to different soil in Egypt. Communication Soil Science Plant Annals. 29: 2067-2088.

GUNNNARSON C. C. \& PETERSON C. M. 2006. Eichhornia crassipes (Water hyacinth) as resources in agriculture and energy production: a literature review. Waste Management. 27(1): 117-129. https://doi.org/10.1016/j.wasman.2005.12.011

MAISHANU H. M., MAINASARA M. M., ALIERO B. L., ISAH A. D. \& OJONUQWA S. E. 2017. Effect of fire on biomass accumulation and productivity of herbaceous plants in the permanent site, Usmanu Danfodiyo University Sokoto, Sokoto State, Nigeria. International Journal of Research and Review. 4: 6-13.

MAKINDE E. A. \& AYOOLA A. A. 2008. Residual influences of early season crop fertilization and cropping system on growth and yield of Cassava. American Journal of Agriculture and Biological Science. 2(3): 19-22. https://doi.org/10.3844/ajabssp.2008.712.715

MAKINDE E. A., AYENI L. S. \& OJENIYI S. O. 2011. Effect of organic, organomineral and NPK fertilizer treatments on the nutrient uptake of Amaranthus cruentus. Journal of Central European Agriculture. 12: 114-123. https://doi.org/10.5513/JCEA01/12.1.887

MAKINDE E. A. \& AYOOLA O. T. 2012. Comparative growth and yield of Okra with Cow dung and poultry Manure. American-Eurasian Journal of Sustainable Agriculture. 6(1): 18-23.

NDIMELE P. E., KUMOLU-JOHNSO C. A. \& ANETEKHAI M. A. 2011. The invasive aquatic macrophyte, (Eichhornia crassipes) Water Hyacinth problem and prospects. Resource Journal of Environmental Sciences. 5: 509-520. https://doi.org/10.3023/rjes.2011.509.520 
NDIMELE P. E. 2012. Effect of (Eichhornia crassipes) Water Hyacinth infestation on the physico-chemistry, nutrient and heavy metal content of Badagry Creek and Ologe Lagoon, Lagos Nigeria. Journal of Environmental Science and Technology. 5(2): 128-136. https://doi.org/10.3923/jest.2012.128.136

NGULDE Y. M., YERIMA I. \& ABUBAKAR M. 2018. Evaluation of Cow dung and Goat Pellets of Biogas in University of Maiduguri, North-Eastern Nigeria. African Journal Environment and Natural Science Research. 1: 33-43.

NUKA L. \& DUBEY V. 2011. Response of Water Hyacinth manure on the growth and yield of Brassica juncea. Journal of Central European Agriculture. 12(2): 336-343.

OJENIYI S. O., AMUSAN O. A. \& ADEKIYA A. O. 2013. Effect of poultry manure on soil physical properties, nutrient uptake and yield of cocoyam (Xanthosoma saggitifolium). African-Eurasian Journal of Agricultural and Environmental Sciences. 13(1): 121-125. https://doi.org/10.5829/idosi.aejaes.2013.13.01.1861

OKWUAGWU M. I., ALLEH M. E. \& OSEMOWOTA I. O. 2003. The effect of organic and inorganic manure on soil properties and yield of okra. African Crop Science Conference Proceeding. 6: 390-393.

OLUBUNMI M. S., IMUSU U. M., ADEYINKA E. A. \& SAMUEL A. L. 2011. Comparative effect of mineral fertilizer and organic manures on growth, nutrient content and yield of Chorcorus olitorus and Celosia argetina. Research Journal of Botany. 6(4): 150-156.

OMOTOSO S. O. \& SHITTU O. S. 2007. Effect of NPK fertilizer rates and method of application on growth and yield of okra (Abelmoschus esculentus) at Ado-Ekiti Southwestern Nigeria. International Journal of Agriculture Research. 2: 614-619.

PIRIE N. W. 1955. Modern method of plant analysis. Interscience Publisher Inc. New York: 146-152 pp.

RODALE R. 1984. Alternative agriculture. Journal of Soil and Water Conservation. 39: 294-296.

ZAMAN M. M., CHOWDHURY T., NAHAR K. \& CHOWDHURY M. A. H. 2017. Effect of Cow dung manure on the growth, leaf biomass yield of Stevia rebaudiana and post-harvest soil fertility. Journal of Bangladesh Agricultural University. 15(2): 206-211.

SEYEDBAGHERI M. M. 1999. Evaluation of compost organic manure on crops. State Organic Growers Annual Meeting Mountain Home: p.17.

SHARMA A. R. \& MITTRA B. N. 1991. Effect of different rates of application of organic and inorganic manure. Journal of Agricultural Science. 117: 313-318.

SHUKRY W. M., KHATTAB H. K. \& EL-BASSIOUNLY M. 2007. Physical and biochemical studies on Flax plant Grew in calcareous soil amended with Water hyacinth dry manure. Journal of Applied Sciences Research. 3(1): 64-72.

SINGH K. \& SRIVASTAVA O. D. 1970. Effect of organic manures on soil fertility as showed by nutrition availability and yield response in potato. Protection International Symposium of Soil Fertility Evaluation. New Delhi. 1: 815-820.

SMIL V. 2000. Phosphorus in the environment. Natural flows and human interferences. Annual Review of Energy and Environment. 25: 53-88. https://doi.org/10.1146/annurev.energy.25.1.53

SOLOMON W. G. O., NDANA R. W. \& ABDULRAHIM Y. 2012. The comparative study of the effect of organic manure cow dung and inorganic fertilizer N.P.K. on the growth rate of maize. International Research Journal of Agricultural and Soil Science. 2(12): 516-519.

SOOKNAH R. D. \& WILKIE A. C. 2004. Nutrient removal by floating aquatic macrophytes culture in anaerobically digested flushed dairy manure waste water. Ecological Engineering. 22: 27-42.

SRIDHAR M. K. C. \& ADEOYE G. O. 2003. Organo-mineral fertilizers from urban wastes: development in Nigeria. The Nigerian Field. 68(2): 91-11.

URIYO A. P. \& SINGH B. R. 1974. Practical soil chemistry manual. Branch Morogoro University, Dares salaam: 12-14.

YADAV R. S., HASH C. T., BIDINGER F. R., DEVOS K. M. \& HOWARTH C. J. 2004. Genomic regions associated with grain yield and aspects of post flowering drought tolerance in pearl millet across environments and tester background. Euphytica. 136: 265-277.

WIDJAJANTO D. W., MATSUSHILA K., HONMURA T. \& MIYANCH N. 2001. Studies on the release of Nitrogen from Water Hyacinth incorporated in to soil-crop system using ${ }^{15} \mathrm{~N}$ - labelling techniques. Pakistan Journal of Biological Sciences. 4:10754-10777.

\section{How to cite this article:}

SAliHU I. A., ALIERO A. A., AUDU M., MAISHANU H. M., LIMAN A. A. \& MUHAMMAD M. L. 2020. Influence of water hyacinth (Eichhornia crassipes (Mart.) Solms) and cow dung on soil chemical properties and growth of Okra (Abelmoschus esculentus (L.) Moench). J. Plant Develop. 27: 137-149. https://doi.org/10.33628/jpd.2020.27.1.137 